
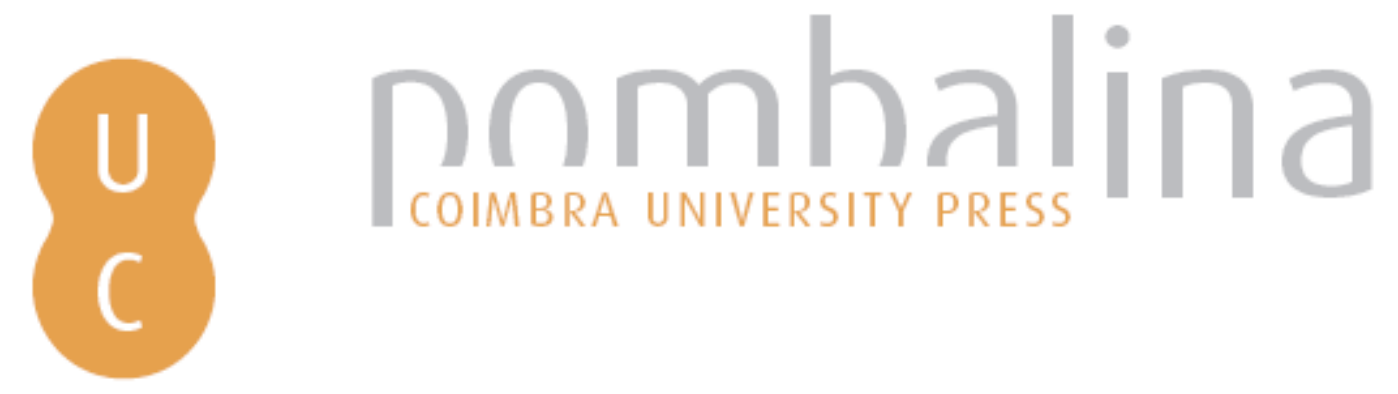

Morfogénese e intenções, planos e projetos de atravessamento da Baixa de Coimbra:
outros contributos de um geógrafo

Autor(es): $\quad$ Fernandes, Mário Gonçalves

Publicado por: Imprensa da Universidade de Coimbra

URL

persistente: URI:http://hdl.handle.net/10316.2/43490

DOI: $\quad$ DOI:https://doi.org/10.14195/978-989-26-1343-7_20

Accessed : $\quad$ 26-Apr-2023 12:34:07

A navegação consulta e descarregamento dos títulos inseridos nas Bibliotecas Digitais UC Digitalis, UC Pombalina e UC Impactum, pressupõem a aceitação plena e sem reservas dos Termos e Condições de Uso destas Bibliotecas Digitais, disponíveis em https://digitalis.uc.pt/pt-pt/termos.

Conforme exposto nos referidos Termos e Condições de Uso, o descarregamento de títulos de acesso restrito requer uma licença válida de autorização devendo o utilizador aceder ao(s) documento(s) a partir de um endereço de IP da instituição detentora da supramencionada licença.

Ao utilizador é apenas permitido o descarregamento para uso pessoal, pelo que o emprego do(s) título(s) descarregado(s) para outro fim, designadamente comercial, carece de autorização do respetivo autor ou editor da obra.

Na medida em que todas as obras da UC Digitalis se encontram protegidas pelo Código do Direito de Autor e Direitos Conexos e demais legislação aplicável, toda a cópia, parcial ou total, deste documento, nos casos em que é legalmente admitida, deverá conter ou fazer-se acompanhar por este aviso.

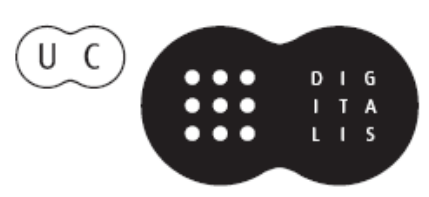




\section{FERNANDA CRAVIDÃO}

\section{IÚCIO CUNHA}

PAULA SANTANA

\section{NORBERTOSANTOS}

(ORG.)

\section{ESPAÇOS E TEMPOS EM GEOGRAFIA}

HOMENAGEM A ANTÓNIO GAMA

IMPRENISA DÁ UNIVERSIDADE DE COIMBRA COIMBRA UNIVERSITY PRESS

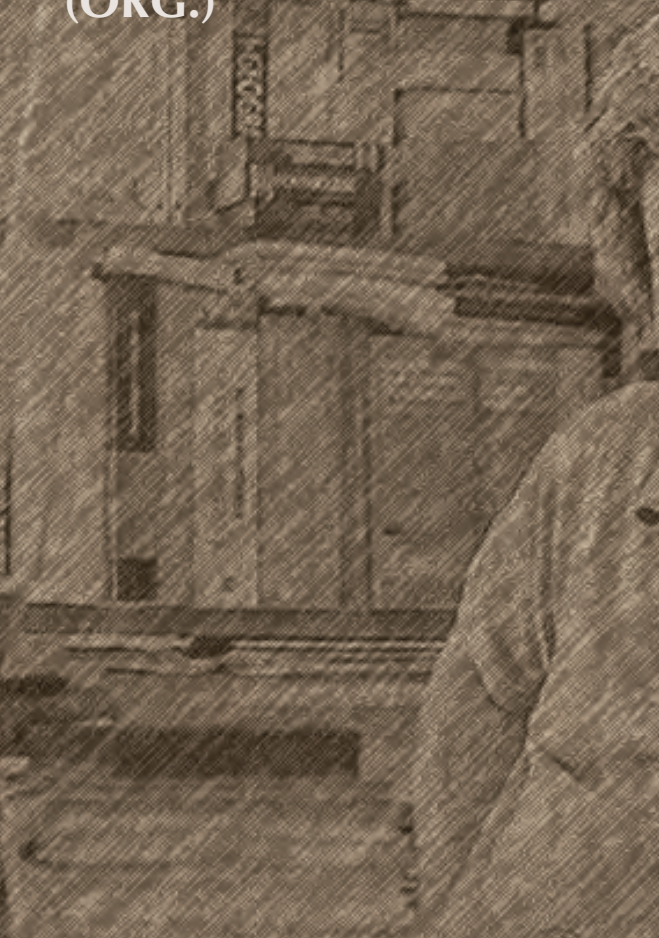




\title{
MORFOGÉNESE E INTENÇÓES, PLANOS E POJETOS DE ATRAVESSAMENTO DA BAIXA DE COIMBRA: OUTROS CONTRIBUTOS DE UM GEÓGRAFO
}

\author{
Mário Gonçalves Fernandes \\ mgfernan@letras.up.pt
}

Departamento de Geografia da Faculdade de Letras da Universidade do Porto

\section{Nota prévia}

Como em publicação de homenagem anterior, a uma geógrafa ${ }^{1}$, também aqui se apresenta um texto preexistente, divulgado em círculos restritos mas não publicado, assumidamente inalterado, que consubstancia parte do contributo de um geógrafo para a construção de um documento que visa a transformação de um território, no caso presente, o Documento Estratégico para a Primeira Unidade de Intervenção na Cidade de Coimbra ${ }^{2}$, que enquadra e enforma a inserção do Metro Ligeiro do Mondego na Baixa da cidade de Coimbra.

A clara relação intrínseca entre a cidade de Coimbra e António Gama Mendes, acrescentada à memória das nossas conversas nas noites de sábado que

1 O texto de 2005, "Plano de Pormenor da Zona Ribeirinha Nascente em Vila do Conde: contributos de um geógrafo”, Porto, Revista da Faculdade de Letras, Geografia, I Série, Vol. XIX: 429-439; em homenagem à Profa Rosa Fernanda Moreira da Silva.

2 2007, Documento Estratégico para a Primeira Unidade de Intervenção na Cidade de Coimbra, Coimbra Viva SRU - Sociedade de Reabilitação Urbana, S.A. (policopiado, coordenação c/ Rui Passos Mealha). 
mediavam o meu labor de estudante de mestrado na Coimbra da década de 1990, fazem com que a adequação deste texto como pequena parcela do livro em sua homenagem se me apresente evidente. Além do mais, relendo o texto, reencontro-o atualizado, importando apenas acrescentar alguns contributos de

referência recente ${ }^{3}$, que, no essencial, confirma, com a investigação, os pressupostos estribados na experiência de investigaçóes sobre outras cidades.

Enquanto geógrafo, mantenho a ideia de carrear elementos decorrentes da análise morfogenética para, pelo debate, contribuir para delinear o concept, a ideia conceptual geradora subjacente à proposta de plano e/ou projeto de intervenção.

Optando por alimentar a reflexão em torno do papel do geógrafo na conceção da ação sobre o território a esta escala, continuam a considerar-se pertinentes as referências de há cerca de uma década, sublinhando-se que é na compreensão do lugar que, com arrojo e ponderação, deve assentar uma das âncoras incontornáveis do plano e/ou projeto.

\section{Morfogénese urbana}

Quer literalmente, no âmbito geomorfológico, quer por analogia, no que à morfologia urbana concerne, a Baixa de Coimbra é uma área de sedimentação prolongada. Náo o é menos a Alta, naturalmente, onde o povoamento assentou origens, talvez pré-romanas, num morro calcário desde cedo fortificado, para a resistência luso-romana às invasões Bárbaras (Martins, 1983, 1. ${ }^{a}$ edição 1951: 41 e 44-45), e cujos muros seriam sucessivamente reforçados e renovados até serem parcialmente substituídos, nas intervenções pombalinas, com o seu chão transformado em eixos de articulação entre a Alta e a Baixa, as couraças (Rossa, 1997: 307). As suas portas não atingiam a planície de inundação (Rebelo, 1999: 11) do Mondego, cujo contínuo assoreamento, apesar dos inelutáveis soterramentos,

3 2015, Margarida Isabel Barreto Relvão Calmeiro, Urbanismo antes dos Planos: Coimbra 1834-1934, Doutoramento em Arquitetura, na Especialidade de Teoria e História de Arquitetura Departamento de Arquitetura da Faculdade de Ciências e Tecnologia da Universidade de Coimbra. 
foi insuficiente para impedir a formação e desenvolvimento de um arrabalde ribeirinho. Este, pela posição privilegiada enquanto encruzilhada de caminhos protegida pelas muralhas e aproveitando as facilidades de um vau estreito e seguro, reforçadas pela ponte que a técnica romana terá edificado, tornar-se-ia, além de ponto de passagem, num lugar de pausa na progressão, propiciador do trato comercial (Martins, 1983, 1. a edição 1951: 44-45).

Como para a Alta, também a data da génese da Baixa de Coimbra é indeterminada e, embora seja factualmente seguro precisar a existência de nódulos morfogenéticos no século XII e a generalidade das suas ruas estejam atestadas apenas a partir do século XII (Alarcão, 1999: 3), o seu esboço terá sido certamente anterior. De qualquer forma, como A. Fernandes Martins esquematizou no seu esboceto (Figura 1), no século XII estavam constituídos os elementos fundamentais geradores e agregadores da Baixa coimbrã: a porta da Almedina, as igrejas paroquiais então reconstruídas (S. Bartolomeu, S. Tiago e Santa Justa) e o mosteiro de Santa Cruz. Todos marcadamente articulados pela estrada Norte-Sul, que seguia desde o Arnado pelas ruas dos Caldeireiros (depois rua Direita, porque direta a Santa Cruz), do Coruche (actual Visconde da Luz), dos Francos (atual Ferreira Borges) e pelo Largo da Portagem, ancorando-se na ponte sobre o Mondego, então mandada edificar por D. Afonso Henriques.
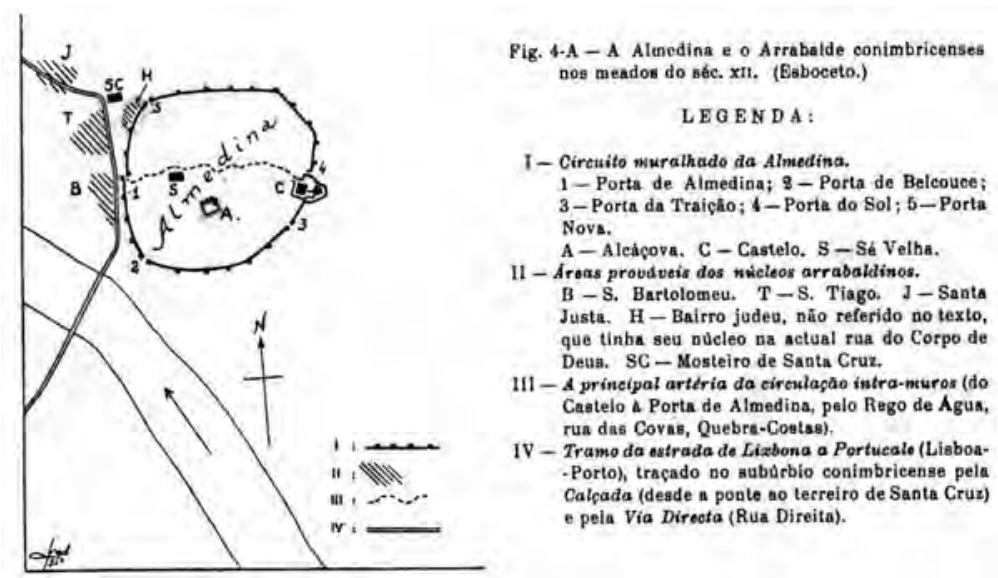

\section{Figura 1}

Esboceto de A. Fernandes Martins (1983, 1. a edição 1951: 52) 
Papel relevante terá sido o do Mosteiro de Santa Cruz consubstanciando-se como fator essencial de desenvolvimento de toda a Baixa. De facto, integrando o Vale da Ribela na sua cerca e assim contendo a progressão do casario vale acima (o que só aconteceria na segunda metade do século XIX, possibilitado pela desamortização dos bens das ordens religiosas ocorrido em 1834) “o mosteiro cedo promoveu uma característica operação de urbanização no espaço compreendido entre si e o rio, um primitivo núcleo rural em torno da primitiva Igreja de Santa Justa a norte e a extensão em 'baixa' da cidade Alta a sul, não sem prover na criação do espaço intermédio que hoje é um dos principais polos de centralidade da cidade, a Praça 8 de Maio”, como explicitou Rossa (2005: 3-4).

Paulatinamente, a malha urbana da Baixa foi-se estruturando, com uma morfologia genericamente orgânica (Rossa, 2005: 4) nas proximidades das igrejas paroquiais e mais ordenada defronte do Mosteiro de Santa Cruz, de onde irradiam as ruas da Moeda e da Louça. A Quinhentista, retilínea e desafogada, Rua da Sofia (que se constituiria na nova saída da cidade, secundarizando a rua Direita) viria completar a estrutura geral em "leque", nodolizado na Praça 8 de Maio e virado aos cais da margem do Mondego, então eventualmente mais próxima e irregular.

Cedo a cidade se recentraria funcionalmente na Baixa, com a intensificação da azáfama de artesãos e comerciantes, aprofundada e diversificada com a localização dos conventos das ordens mendicantes na periferia próxima e, depois, com os colégios da Rua da Sofia, função a que ficou limitada após a frustrada instalação da Universidade. De facto, a Rua da Sofia, "aberta como instrumento inicial da instalação da Universidade e produzida, financeira e urbanisticamente à custa e a partir do Mosteiro de Santa Cruz", mostrar-se-ia insuficiente para o desenvolvimento ulterior da Universidade, afinal definitivamente localizada na Alta, que assim seria reanimada porque "reformada em peculiar e arcaico/ precoce campus universitário” (Rossa, 2005: 6).

Conformava-se, assim, a dual Coimbra quinhentista, segundo a prosa de Martins (1983, 1. a edição 1951: 58): "dual na topografia e no acomodar dos moradores - na Almedina, a vida estuante dos escolares, as maneiras comedidas 
dos familiares do paço episcopal; na Baixa, o povo agremiado, a atividade dos oficiais mecânicos, os burgueses dados ao comércio". Esta dualidade perduraria até ao século XIX, sendo aprofundada pelas intervençôes pombalinas na Alta (1772/73), aqui vertidas num "urbanismo regrado (...) feito de formas e objetos arquitetónicos e não de grelhas viárias ou arruamentos" (Rossa, 1997: 308) e pelo encanamento artificial do Mondego, quando estava em curso o ano de 1791 (Martins, 1983, $1^{\text {a }}$ edição 1951: 62), o qual, além de explicar a mata do Choupal, minimizaria a irregularidade do regime fluvial e as dificuldades da navegabilidade.

Apesar de tudo, chegado o século xix, Coimbra mantinha-se uma cidade pequena, como afirmou Martins (1983, 1. a edição 1951: 63), "ou seja, a velha Almedina mais o casario da Baixa - que, alongando-se da Portagem à rua do Carmo, formava conjunto contínuo mas sem beirar o rio -, alguns colégios para além do Carmo e o arruado de Fora-de-Portas. Era tudo. Isso mesmo pode ser verificado pela observação da Planta Topographica da Cidade e Arredores de Coimbra" (Figura 2), levantada e desenhada em 1845, por Izidoro Emílio Baptista, estudante da Universidade de Coimbra, que Martins (1983, 1. a ediçáo 1951) copiou e reproduziu (Figura 3). De facto, apenas na segunda metade de Oitocentos esta realidade sofreria alteraçôes, decorrentes do contexto de estabilização política que permitiu a concretização da política fontista de melhoramentos materiais, visando a formação e articulação de um espaço económico nacional e consubstanciada na melhoria da navegação fluvial e nas obras portuárias e na construção das rede ferroviária e de estradas, assente na ideia do livre trânsito, quer entre as povoaçóes como no seu atravessamento, à qual se acrescentariam as preocupaçóes higienistas de incremento da salubrizaçáo dos aglomerados urbanos. 


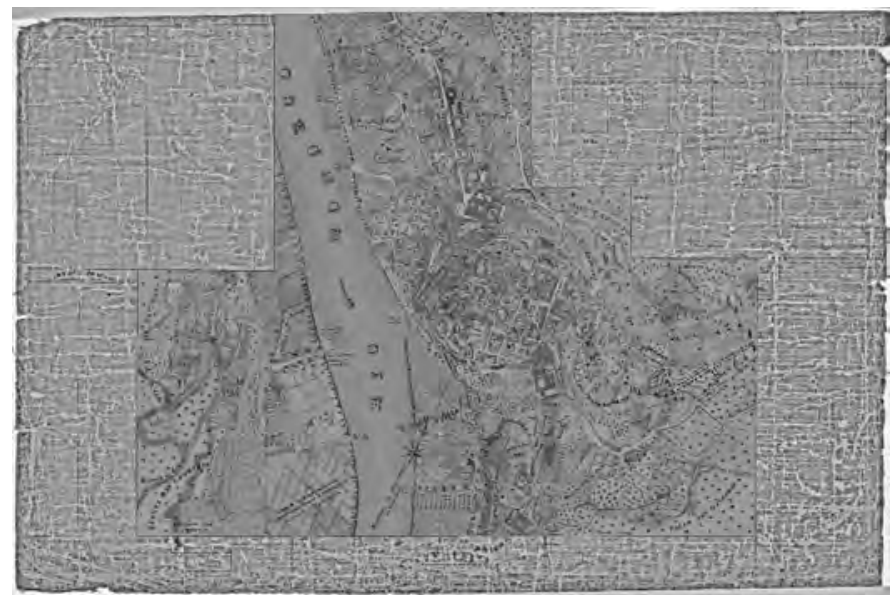

Figura 2

Original da Planta Topographica da Cidade e Arredores de Coimbra, levantada e desenhada, em 1845, por Izidoro Emílio Baptista

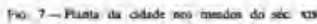

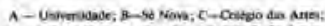

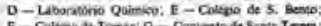

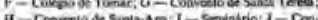

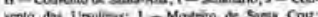

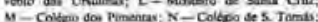

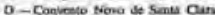

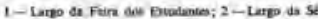

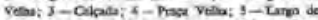

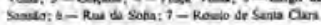

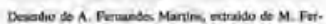

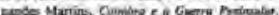

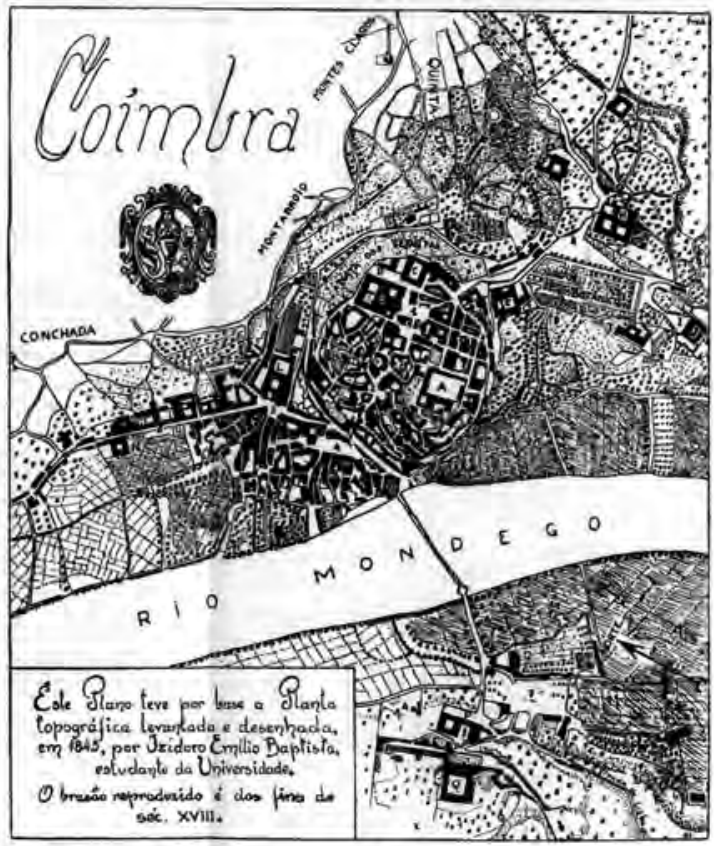

Figura 3

Cópia da Planta Topographica da Cidade e Arredores de Coimbra, reproduzida por Martins (1983, 1. ${ }^{a}$ ediçáa 1951: 58-59) 
É então que, como noutras cidades do país, Coimbra registaria importantes transformaçóes decorrentes do progresso material e da inovaçáo técnica coeva. Assim, apesar de intervenções anteriores, na década de setenta realizam-se os trabalhos definitivos e mais consistentes (Macedo, 2005: 2) da regularização e aterros que permitiram elevar a cota da margem direita do Mondego e a abertura, em 1888, do tramo Norte da avenida Emídio Navarro. Em 1875 concluiu-se o processo de redesenho do largo da Portagem e de construção de uma nova ponte no lugar da estreita ponte do O. Entre 1857 e 1866, por ter sido designada como integrante da estrada real e por isso necessitar de se ajustar aos parâmetros legalmente definidos para a sua classe de estrada (Fernandes, 2005: 100-110), foi alargada e regularizada a rua de Coruche (entáo renomeada de Visconde da Luz).

Em 1864 chegaria o caminho de ferro à Estação Velha (Coimbra B), que por ser afastada da cidade leva à concretização, em 1874, do primeiro serviço urbano de transporte de passageiros, em carros americanos, o qual viria a ser suspenso, em 1885, com a construção do ramal ferroviário até à Estação Nova. Os transportes urbanos, agora com tração elétrica, apenas se reiniciariam em 1911 (Figura 4), entáo potenciados pelo crescimento da cidade pelo vale do Ribelas (entâo já pertencente ao domínio público), concretizado nas décadas de oitenta e noventa do século XIX, nomeadamente com a abertura da rua Olímpio Nicolau Rui Fernandes, da avenida Sá da Bandeira e da praça de D. Luís (hoje da República), constituindo-se esta como rótula de articulação do conjunto de arruamentos da expansão (inaugurada em 1888 - Alarcão, 1999: 5), nomeadamente do Bairro de Santa Cruz e da ligação, finalmente facilitada à parte Alta da cidade.

Antes, em 1867, havia sido inaugurado o mercado municipal D. Pedro V, no lugar da antiga horta de Santa Cruz, e em 1879 realizara-se "a primeira sessão pública camarária na obra ainda inacabada” do novo edifício municipal, o qual, congregando a cada vez mais complexa e diversificada burocracia camarária (decorrente da criação de novos serviços como a iluminação urbana a gás, de 1856, o cemitério municipal da Conchada, de 1860, ou o saneamento da cidade, concluído em 1893 - Costa et al., 1893: 25), mas também "as 
dependências do Estado, tribunais, cartório, conservatório e escola” (Macedo, 2005: 4), viria reforçar a centralidade do largo 8 de Maio.

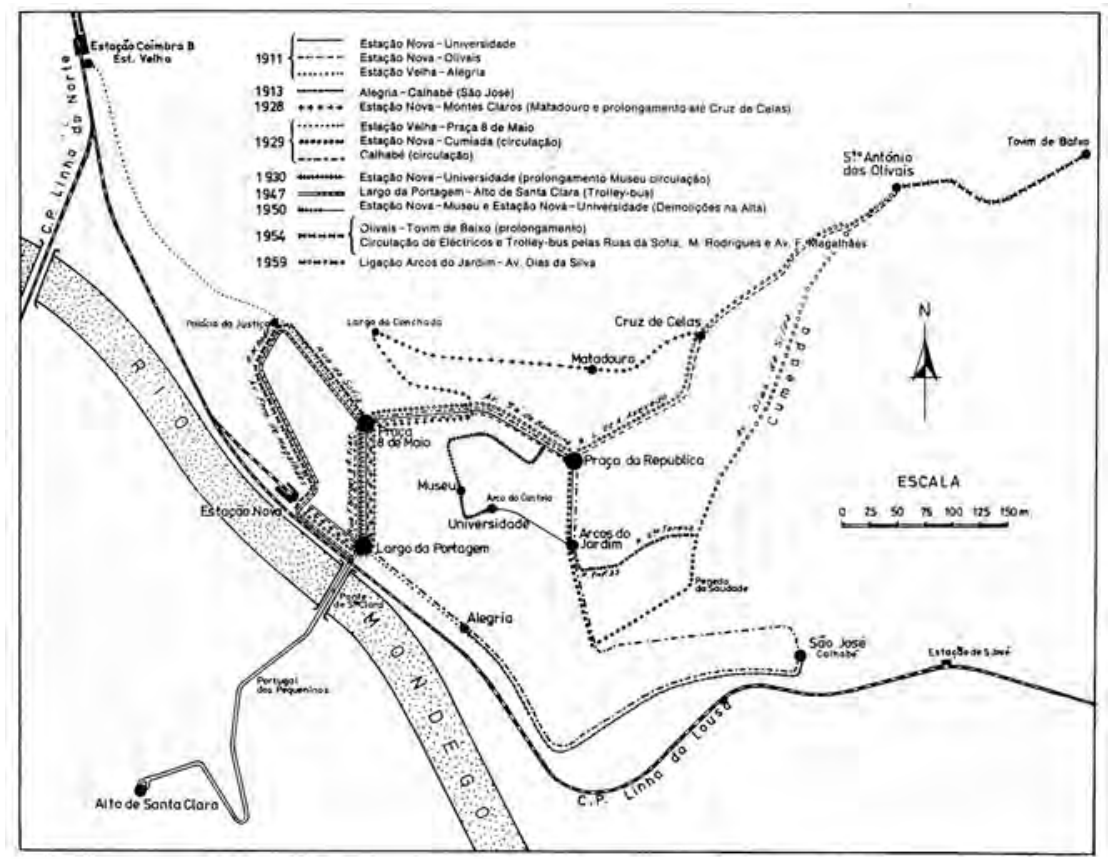

Figura 4

Redes dos transportes urbanos de tração elétrica em Coimbra

Fonte: Matos, 1986: 206.

Naturalmente, como se depreende, além dos investimentos do poder central, muito se deveu à iniciativa complementar do poder municipal. De facto, como noutras povoaçóes, também em Coimbra o poder municipal tratou de promover o levantamento de cartografia rigorosa e de grande escala, consubstanciada na Planta Topográfica de Coimbra (Figura 5) levantada em 1873/74 (na escala de 1:500 e por João Alexandre Cesar Goullard e Francisco Aimé Goullard, os quais são também autores, juntamente com Carlos Pezerat da Carta Topográfica da Cidade de Lisboa, de 1856/58 e na escala de 1:1000, sendo o Francisco também 
autor da Planta de Braga, na escala de 1:500 e de 1883/84), para sobre ela traçar o seu plano de melhoramentos (Macedo, 2005: 5), concretizando na década de oitenta a possibilidade prevista pelo Decreto de 31 de Dezembro de 1864, primeiro documento de abrangência nacional relativo ao planeamento urbano em Portugal. Aí se delineou a expansão da cidade, que a Planta da Cidade de Coimbra, na escala 1:2000 e que pensamos ser de finais do século xix, já apresenta (Figura 6). Aliás, a planta, que segundo o Arq. José Santiago Faria se encontra no Museu Nacional Machado de Castro, pode estar relacionada com o plano de melhoramentos, efetuado ou a efetuar.

Finalmente, já durante a Primeira República, mas prolongando os princípios urbanísticos Oitocentistas, terá sido concretizado o Parque da Cidade, aproveitando o anterior aterro decorrente da regularização do Mondego e ter-se-á concluído a retificação e alargamento da rua da Madalena, ambos já marcados na Planta Topográfica da Cidade de Coimbra, levantada em 1932/34 (Torres, 2005: 5) e da autoria de José Baptista Lopes (Figura 7). Pela observação deste documento pode verificar-se que, apesar dos séculos e das transformaçôes Oitocentistas, a Baixa que ficara definida no século xvi continuava quase intacta a nascente da rua da Madalena e assim se manteria até às últimas décadas do século $\mathrm{xx}$, apesar das várias intenções e projetos de transformação.

Apesar das demoliçóes encetadas pelo Estado Novo a partir de 1942 (Rosmaninho, 2005: 5), que arrasaram parte da Alta coimbrã, e da expansão moderna da Baixa a Norte do Arnado, a malha urbana tradicional da Baixa, a Baixinha, manter-se-ia inalterada, mantendo, no entanto, o seu papel proeminente na vida económica da cidade. Disto nos deixou testemunho A. Fernandes Martins e Sant'Anna Dionísio, com o primeiro a sublinhar os aspetos funcionais ao referir que "na zona chã rente ao rio, a Baixa, de estreitas e tortuosas ruas, conjugada com o Arnado, de artérias largas e traçadas a tira-linhas, não deixou de ser uma colmeia apinhada e é a sede eleita das atividades comercial e industrial" (Martins, 1983, 1a edição 1951: 76); e com o segundo a relevar as questôes morfológicas quando caracterizava a Baixa como "constituída por um aglomerado de quarteirôes antiquados e dispostos numa inextricável rede de ruas muito estreitas e tortuosas” (Dionísio, 1993, 1. a edição 1944: 205), 
salientando-a como exemplo de uma "impressão bem aproximada e sugestiva do que seria uma cidade antiga, na qual, em alguns recantos o sol dificilmente consegue penetrar e onde as casas, escuras e bastante altas, são táo vizinhas, que quase se beijam pelos bicos dos beirais, com os alinhamentos a fazerem os mais imprevistos rodeios" (Dionísio, 1993, 1. a edição 1944: 209).

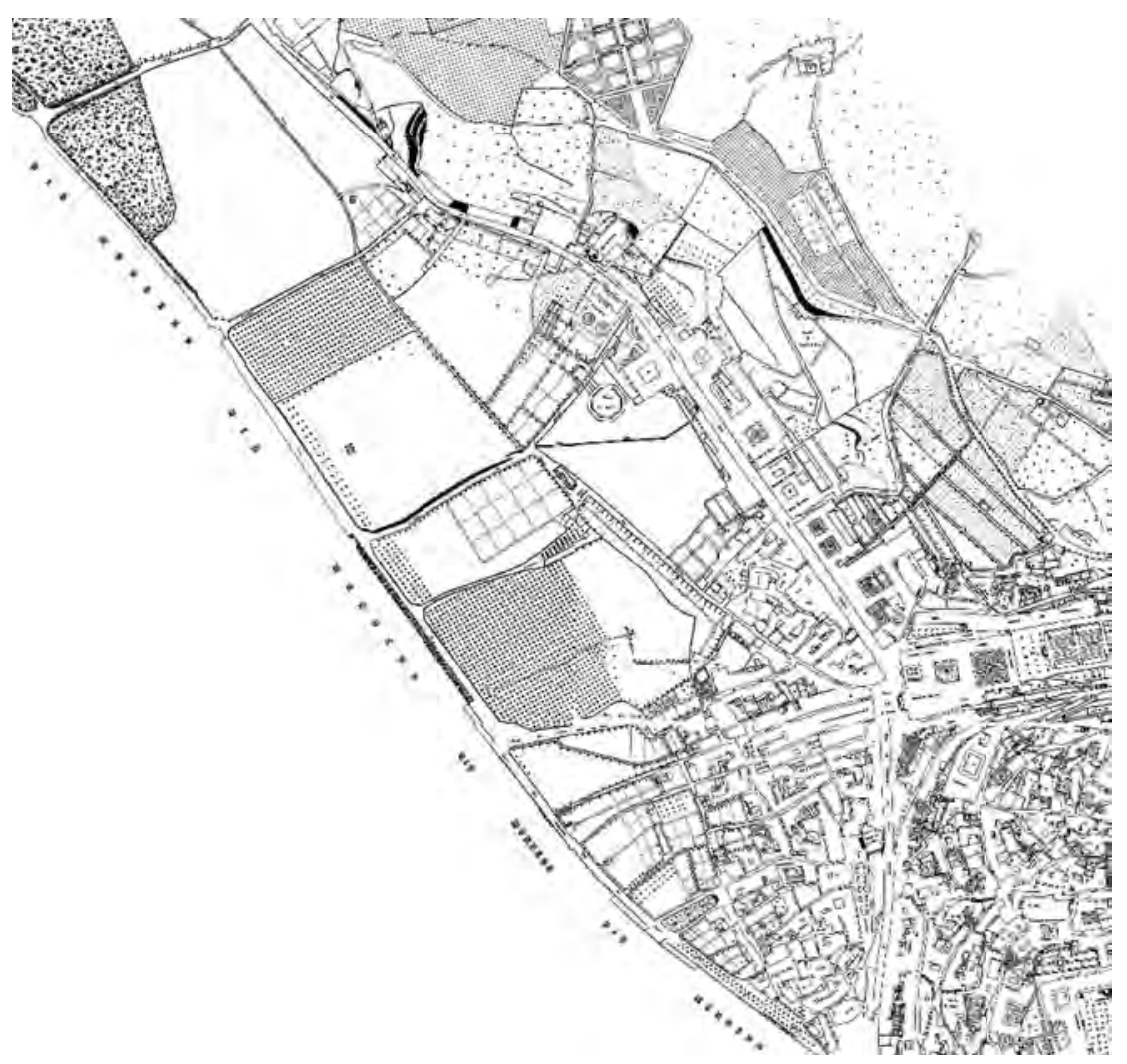

Figura 5

Reprodução reduzida e parcial da Planta Topográfica de Coimbra, de 1873/74 


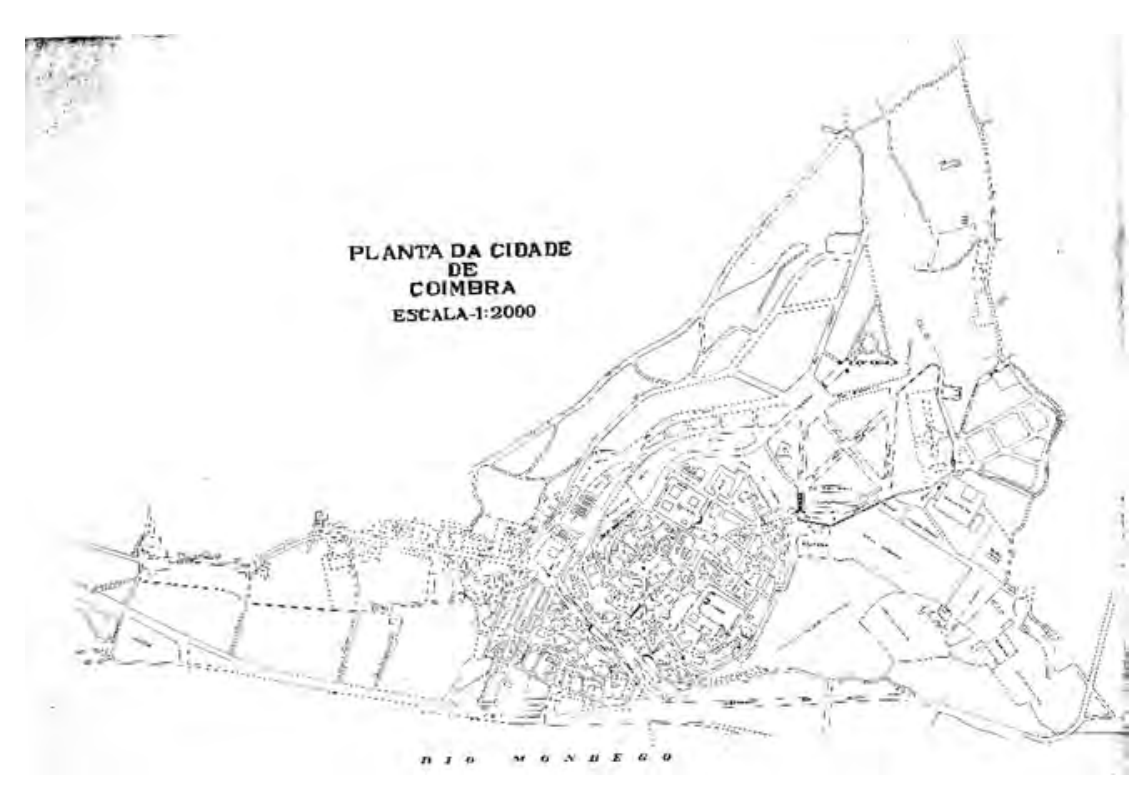

Figura 6

Planta da Cidade de Coimbra, c. finais do século XIX

\section{Intenções, planos e projetos de atravessamento da Baixa}

Náo foi pela falta de ideias, intençóes, planos e projetos que a malha urbana da Baixa perdurou. De facto, logo em 1865, provavelmente impulsionada pela predisposição aberta pelo Decreto de 31 de Dezembro de 1864, sempre visando o "livre trânsito" e a salubrização, terá existido uma "tentativa infrutífera de organizar um plano de melhoramentos da Baixa” (Rosmaninho, 2005: 2). Estas intençóes ganhariam particular acuidade a partir do prolongamento do ramal ferroviário e da construção, em 1885, da nova estação junto ao largo das Ameias, pretendendo-se a articulação fácil da estação ferroviária, ou de suas proximidades, com os locais vitais da cidade, propósito que, aliás, esteve na origem de muitos projetos e concretizaçôes em várias cidades do país. Em Coimbra, esta ideia levaria, desde logo, em 1891, à conceção da abertura de três arruamentos estruturantes, confluindo na estação ferroviária: “a primeira ligaria a Praça 8 de Maio ao Cais dos Oleiros; a segunda estabeleceria comunicação ampla pela 
Rua da Madalena até à Portagem; por fim, a terceira ia pela Rua das Padeiras até à Rua Visconde da Luz" (Rosmaninho, 2005: 2). De todas, apenas se terá iniciado o alargamento da rua da Madalena, já que os restantes implicavam avultados investimentos em expropriaçóes e arrasamentos.

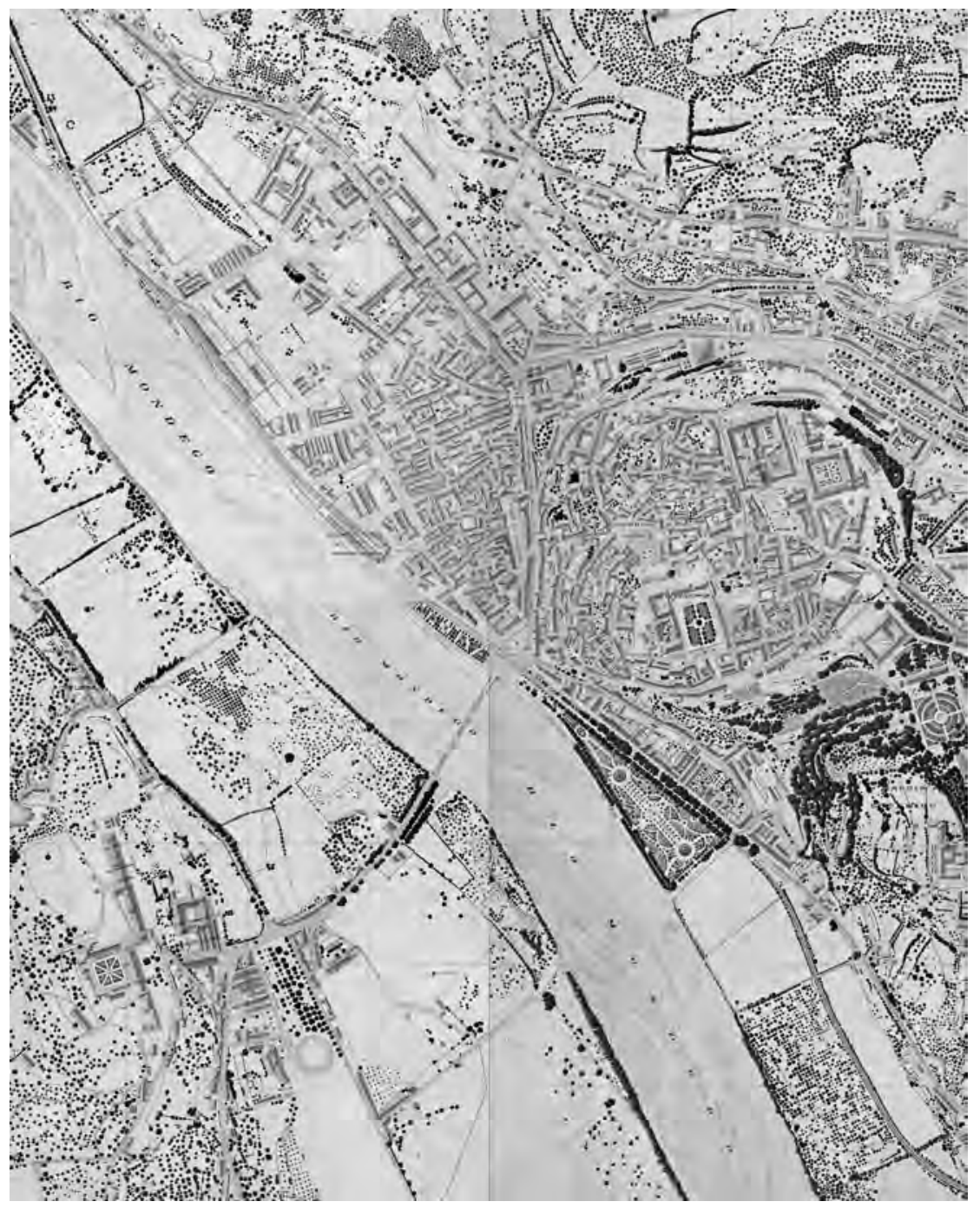

Figura 7

Planta Topográfica da Cidade de Coimbra, 1932/34, de José Baptista Lopes 
Sublinhe-se, como explicitou Rosmaninho (2005: 2), que "foi de arrasamentos que se falou durante setenta anos", sempre que se pensou em intervir na Baixa, ideia que é confirmada, de facto, pela observação de cada um dos muitos planos e projetos elaborados desde o projeto de Abel Dias Urbano, de 1924, até ao estudo urbanístico de Fernando Távora, de 1992, a seguir discriminados:

1924 - Projecto dos novos arruamentos na zona da Cidade limitada por Rua Ferreira Borges, Cais, Largo das Ameias e Praça 8 de Maio, de Abel Dias Urbano;

1936 - Plano de urbanização da parte baixa da cidade, de Luís Benavente;

1940 - Anteprojecto de Urbanização, de Embelezamento e Extensão da Cidade de Coimbra, de Etienne De Gröer;

1955 - Plano Regulador da Cidade de Coimbra, de Antão de Almeida Garrett;

1956 - Plano de Remodelação da Baixa de Coimbra, de Alberto José Pessoa;

1970 - Urbanização da Zona Central da Cidade entre Santa Cruze o Mondego, de Januário Godinho;

1971 - Plano de Urbanização da Baixa, de Manuel Costa Lobo;

1992 - Área Central - Programa de Intervenção, de Jorge Carvalho e Paulo Fonseca;

1992 - Eixo Bota Abaixo/Rio - Estudo Urbanistico, de Fernando Távora.

De facto, nuns casos com maior amplitude e noutros de forma mais contida, sempre esteve pressuposta a intenção de efetuar demoliçóes na Baixa e a necessidade de articular a estação ferroviária e/ou a margem do Mondego com a Praça 8 de Maio ou as suas proximidades, através da denominada Avenida Central (outras vezes de Santa Cruz). A ideia, é de tal modo recorrente que se manteve como o mínimo denominador comum de todos os planos e projetos elaborados. 
Assim, quer o projeto de Dias Urbano (1924), quer o plano de Luís Benavente (1936), faziam tábua rasa da malha medieval existente, como afirmou José Santiago Faria, (2005a : 2). E ambos propunham novas teias de arruamentos, geometrizadas e a assentar o desenho dos eixos principais, provavelmente, no traçado em pata de ganso inspirado em Versailles e então em voga no plano das inglesas cidade-jardim, potenciando, além das questóes funcionais, os efeitos de perspetiva sobre a igreja de Santa Cruz (Figuras 8 e 9).

Etienne De Groër, no seu Anteprojeto, de 1940, apesar de, noutra conceção, se mostrar adepto da cidade-jardim, diminui as demoliçóes, mas mantém a proposta do atravessamento da malha tradicional por dois grandes eixos: um no enfiamento da rua Olímpio Nicolau Fernandes e outro, mais importante, defronte da igreja do antigo mosteiro, a Avenida de Santa Cruz (Figuras 10a e 10b), implicando a demolição da Estação Nova e o seu recuo para jusante (Lusitano dos SANTOS, 1983, p. 12). Antão de Almeida Garrett, no plano regulador de 1955, confirma o esqueleto de arruamentos proposto por De Groër, reafirmando e alargando a Avenida de Santa Cruz, mas limita o prolongamento da rua Olímpio Nicolau Fernandes apenas até à rua Direita (Figuras $11 \mathrm{a}$ e $11 \mathrm{~b})$, mantendo o alargamento desta também anteriormente proposto por De Groër.

As propostas de Alberto Pessoa, no plano de remodelação de 1956, mostram a emergência do urbanismo modernista e a influência da Carta de Atenas, o que, no caso, também implicava, de novo, as demoliçóes generalizadas, aliás explicitamente defendidas ao afirmar que toda a obra válida de urbanização terá forçosamente de constituir uma razia (citado por Faria, 2005a: 7). Do tecido medieval apenas preservava a parte a Sul da nova avenida central proposta, neste caso no enfiamento de Santa Cruz e da câmara municipal (Figuras 12a e 12b).

Januário Godinho, em 1970, circunscreveu-se, explicitamente, à urbanização da Zona Central da Cidade entre Santa Cruz e o Mondego, mantendo as suas variantes de proposta dedicadas à ligação entre aquelas duas áreas: Santa Cruz e Mondego. No entanto, evitou Santa Cruz como enfiamento da avenida, em qualquer das soluçôes (Figura 13). 
Com o plano de Manuel Costa Lobo, de 1971, as avenidas ficam definitivamente afastadas do Mosteiro de Santa Cruz (Faria, 2005a: 8), para se limitar ao enfiamento da rua Olímpio Nicolau Fernandes. Contudo, Costa Lobo introduz um elemento novo: um edifício vazado na continuidade da rua da Sofia, que pretende cerzir o rasgamento provocado por aquele prolongamento (Figura 14). A ideia será retomada em 1992, no Programa de Intervenção de Jorge Carvalho e Paulo Fonseca (Figura 15), para logo desaparecer, ainda no mesmo ano.

De facto, simultaneamente, os serviços camarários conceberam uma solução que, face às demoliçôes já concretizadas, propunha o prolongamento da rua Olímpio Nicolau Fernandes, não incluindo aquele cerzimento. Esta solução seria depois pormenorizadaldesenvolvida (Câmara Municipal de Coimbra, 1993: 29) por Fernando Távora (Figura 16). Entretanto, foi iniciada a execuçáo, a qual, apesar de parcial, foi suficientemente importante, levando à edificaçáo dos incontornáveis novos edifícios do Bota-a-Baixo, cuja concretização já previu os vazamentos para a passagem do metro de superfície.

Antes e depois, a manutenção do projeto de abertura da avenida levaria à demoliçáo de grande parte do velho casario, nomeadamente, e recentemente, aquele que bordejava, pelo Sul, a rua João Cabreira. Agora, há que minimizar estragos, preservando, e evocando, o que for possível da antiga malha urbana, seja pela manutenção do alinhamento da rua da Sofia, pela simbolizaçáo da materializaçáo do edificado na rua Direita, seja ainda através da opção pela organização morfológica tradicional, mantendo o mais possível os quarteirōes existentes nas edificaçóes a concretizar. 


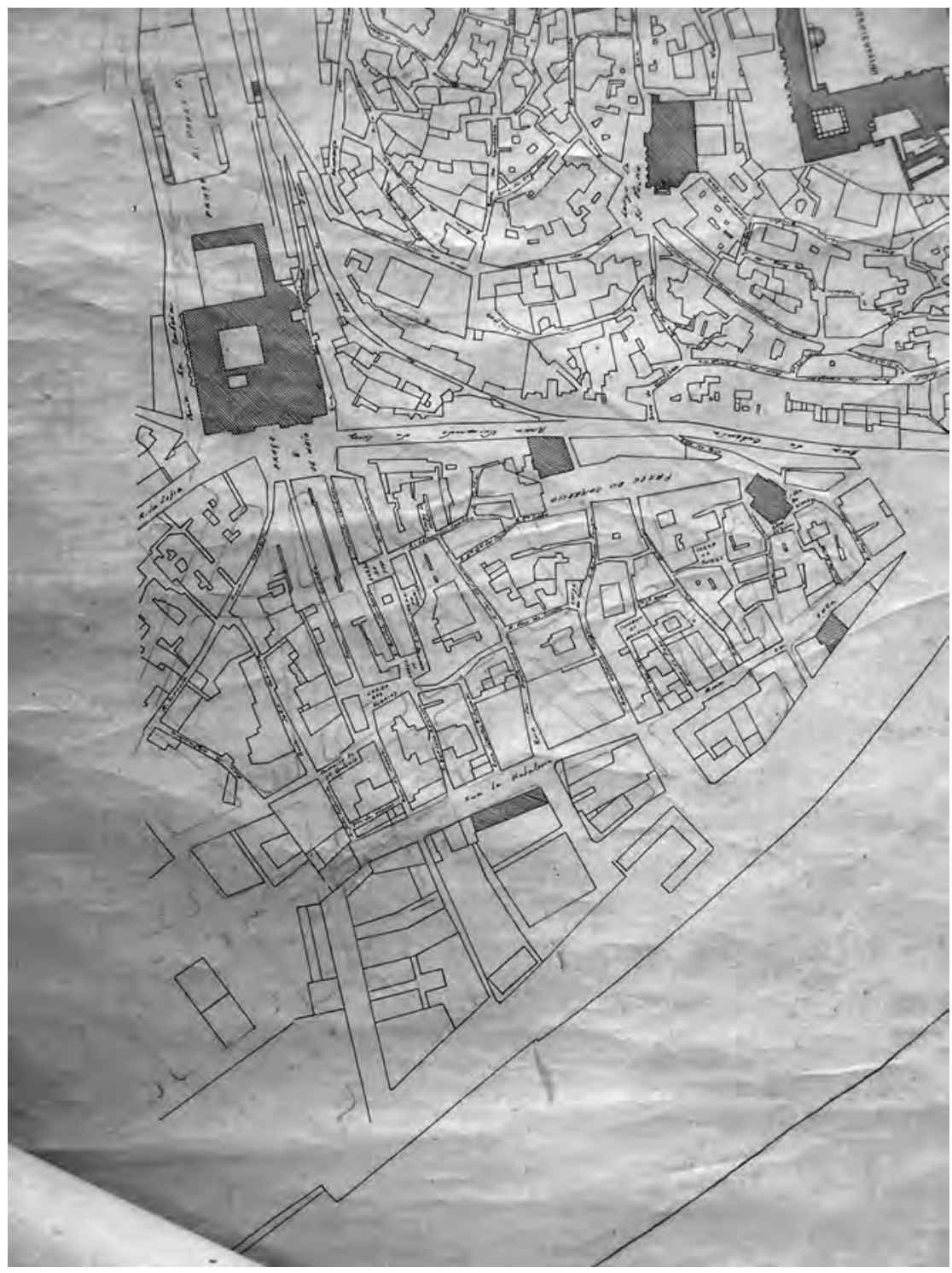

Figura 8

1924 - Projeto dos novos arruamentos na zona da Cidade limitada por Rua Ferreira Borges, Cais, Largo das Ameias e Praça 8 de Maio, de Abel Dias Urbano 


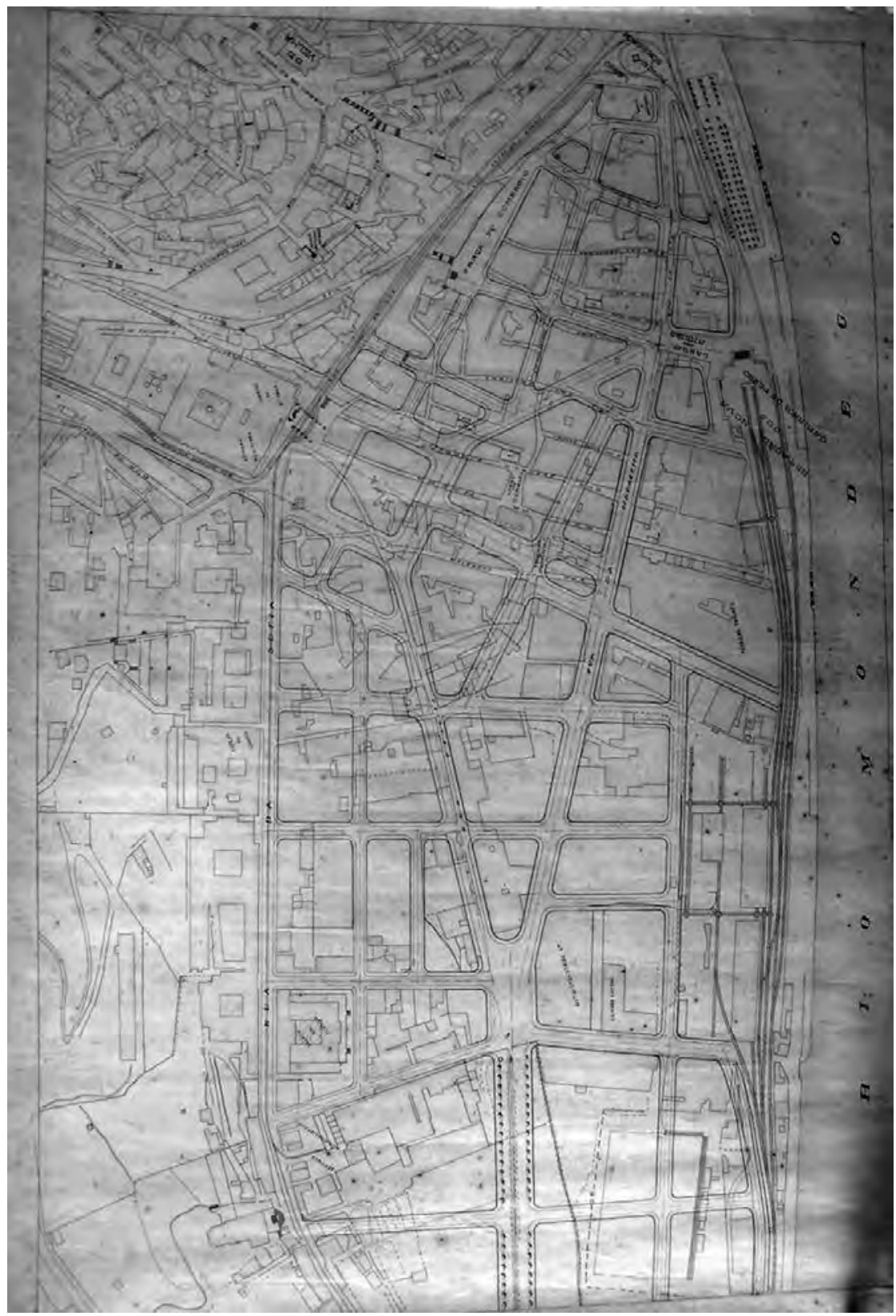

Figura 9

1936 - Plano de urbanização da parte baixa da cidade, de Luís Benavente 


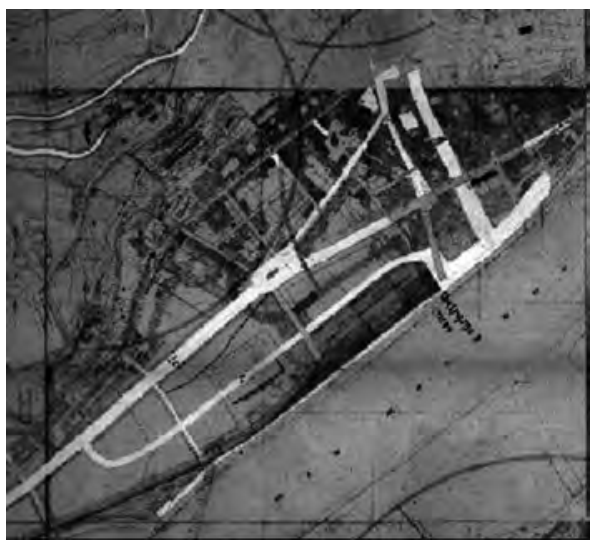

Figura 10a

1940 - Planta do Anteprojecto de Urbanização, de Embelezamento e Extensão da Cidade de Coimbra, de Etienne De Gröer

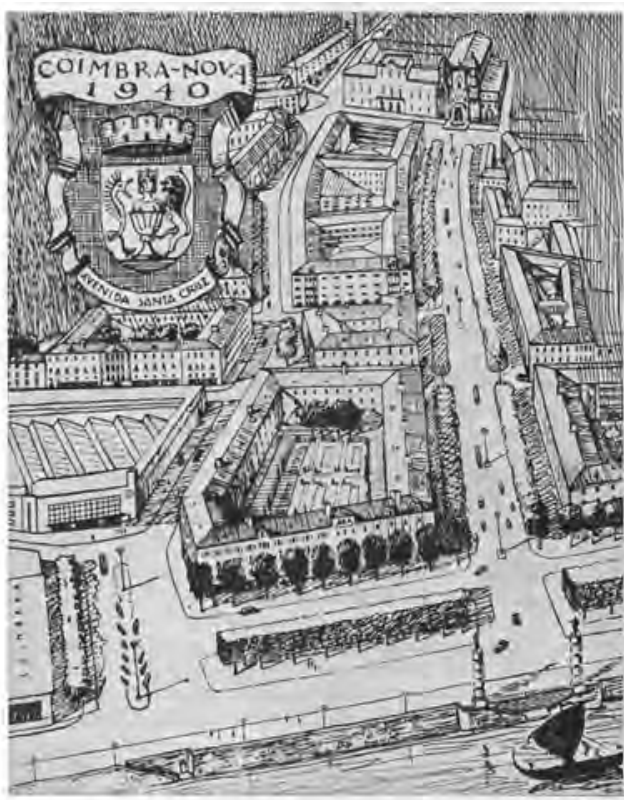

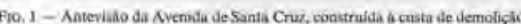

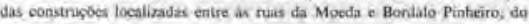

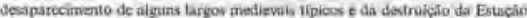

$$
\text { Nova dos Caminhos de Ferro. }
$$

\section{Figura 10b}

1940 - Vista geral da Avenida de Santa Cruz, de Etienne De Gröer.

Fonte: Santos, 1983: 13. 


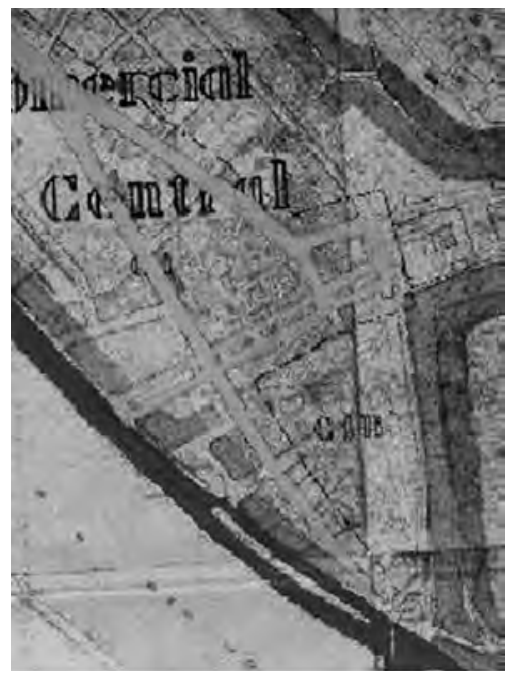

Figura 11a

1955 - Plano Regulador da Cidade de Coimbra, de Antão de Almeida Garrett

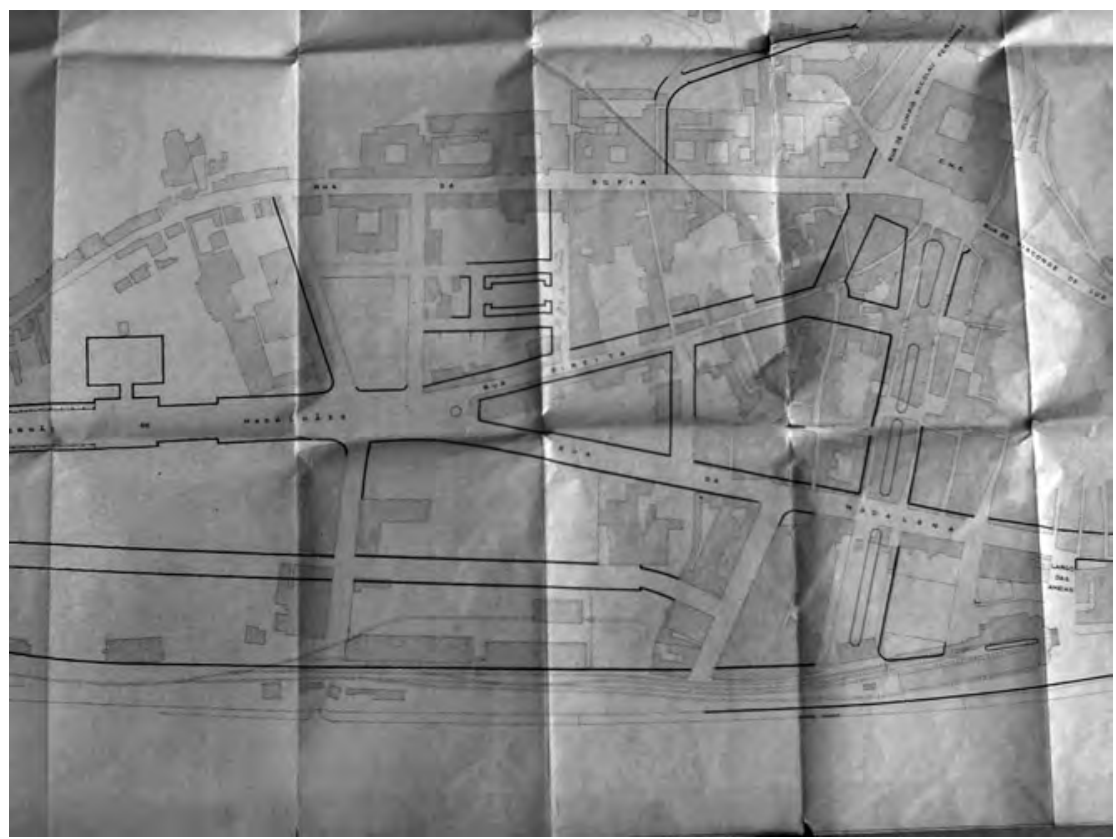

Figura $11 \mathbf{b}$

1955 - Plano Regulador da Cidade de Coimbra, de Antão de Almeida Garrett 


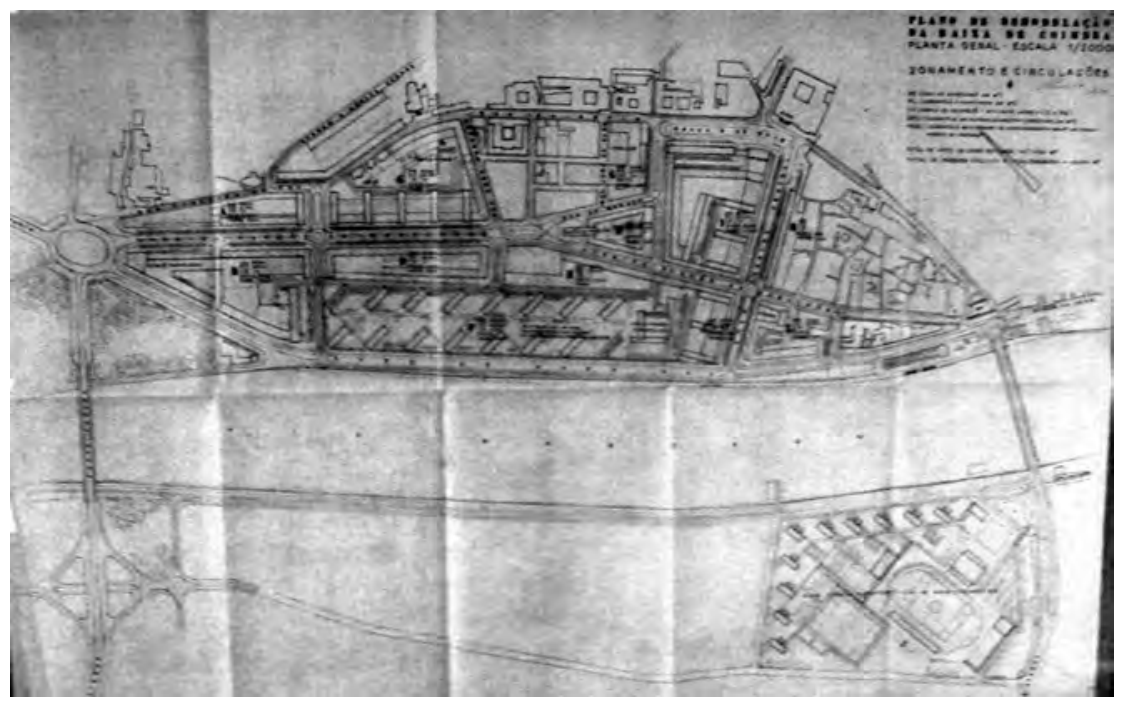

Figura 12a

Plano de Remodelação da Baixa de Coimbra, de Alberto José Pessoa, 1956

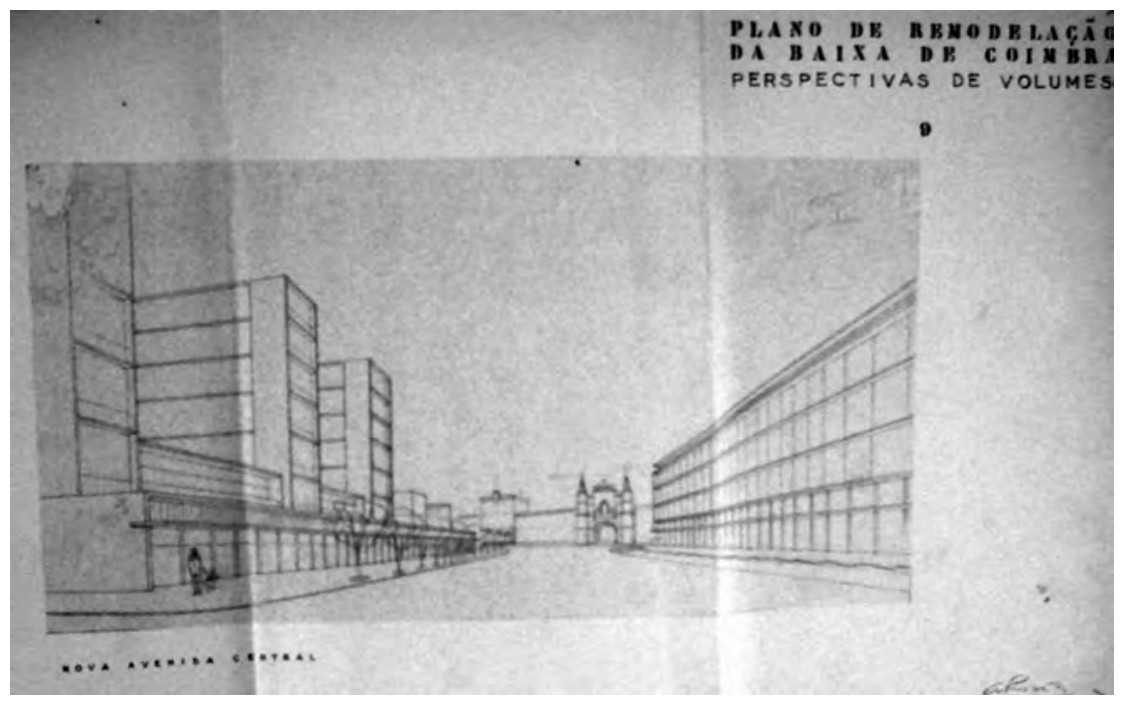

Figura 12b

Perspetiva da avenida da cidade; Plano de Remodelação da Baixa de Coimbra, de Alberto José Pessoa, 1956 

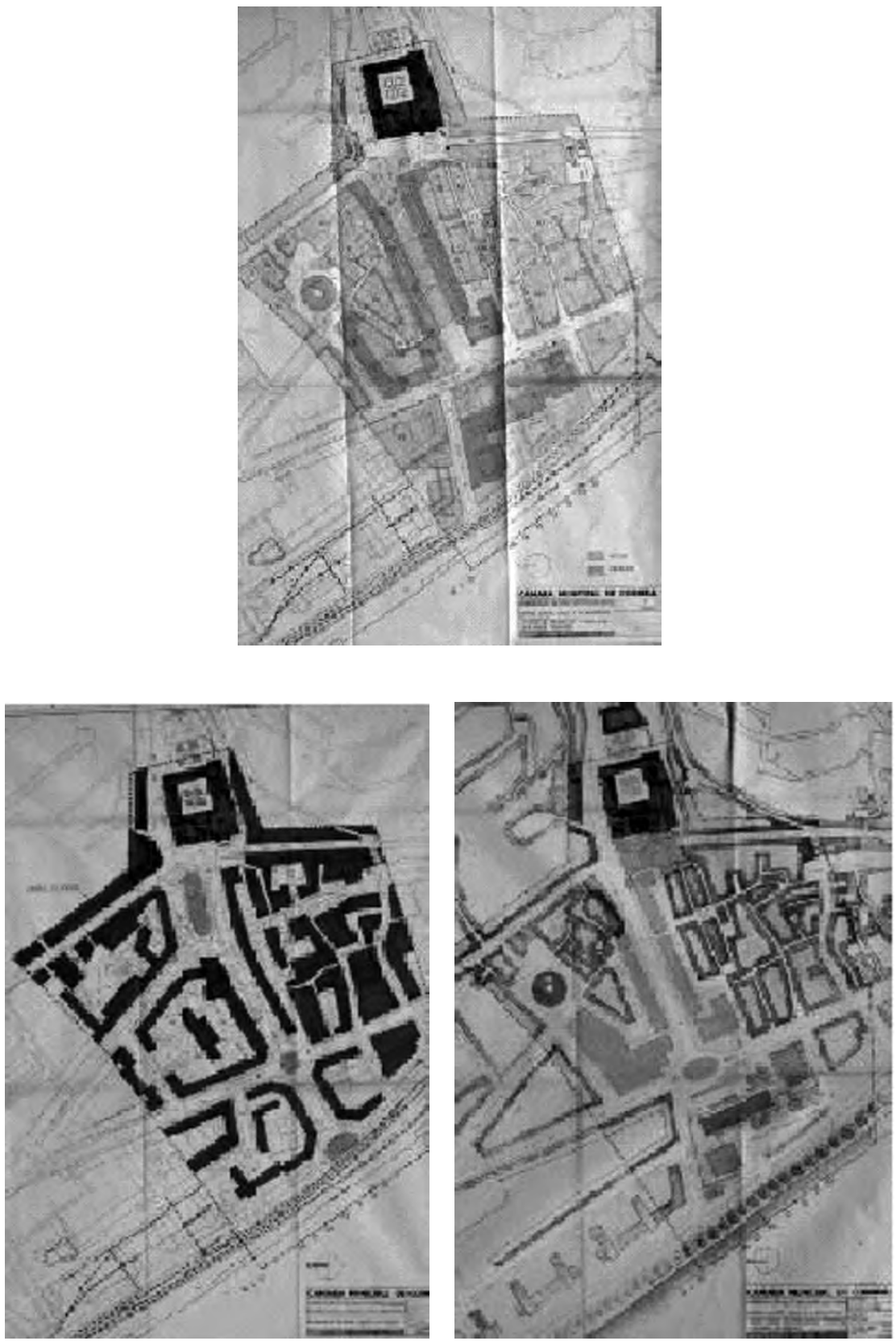

Figura 13

As variantes de Urbanização da Zona Central da Cidade entre Santa Cruz e o Mondego, de Januário Godinho, 1970 


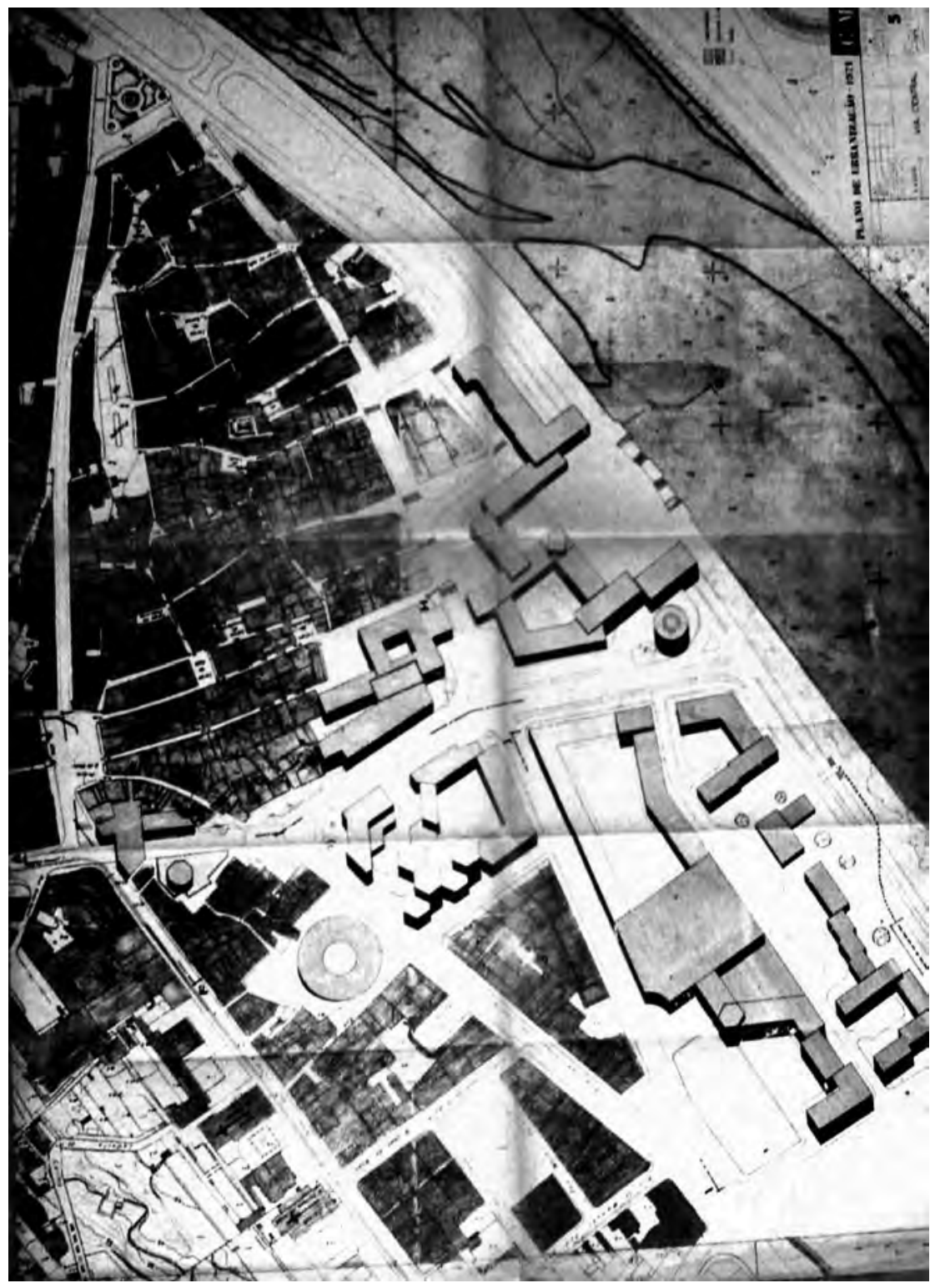

Figura 14

Plano de Urbanização da Baixa, de Manuel Costa Lobo, 1971 


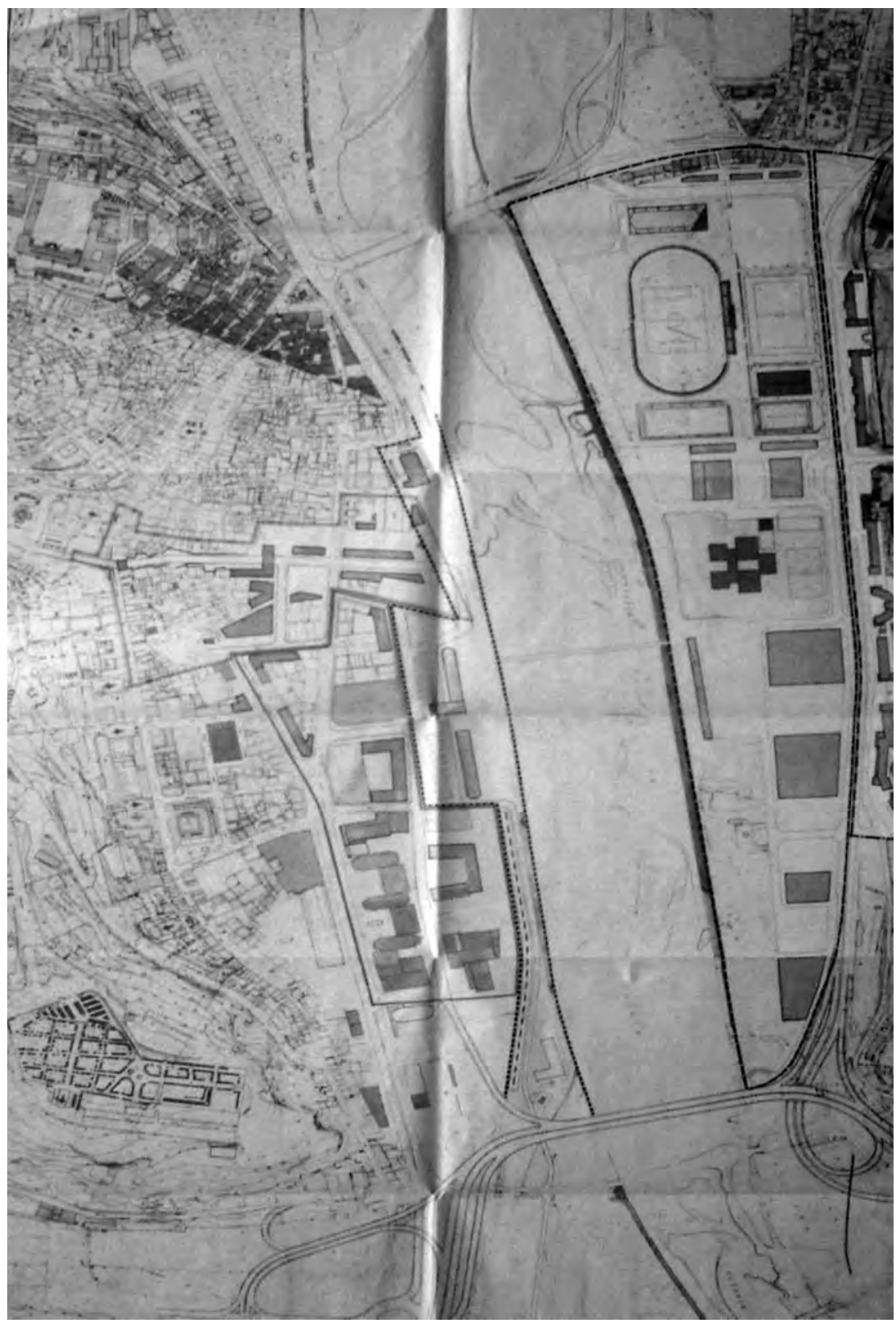

Figura 15

Área Central - Programa de Intervenção, de Jorge Carvalho e Paulo Fonseca, 1992 


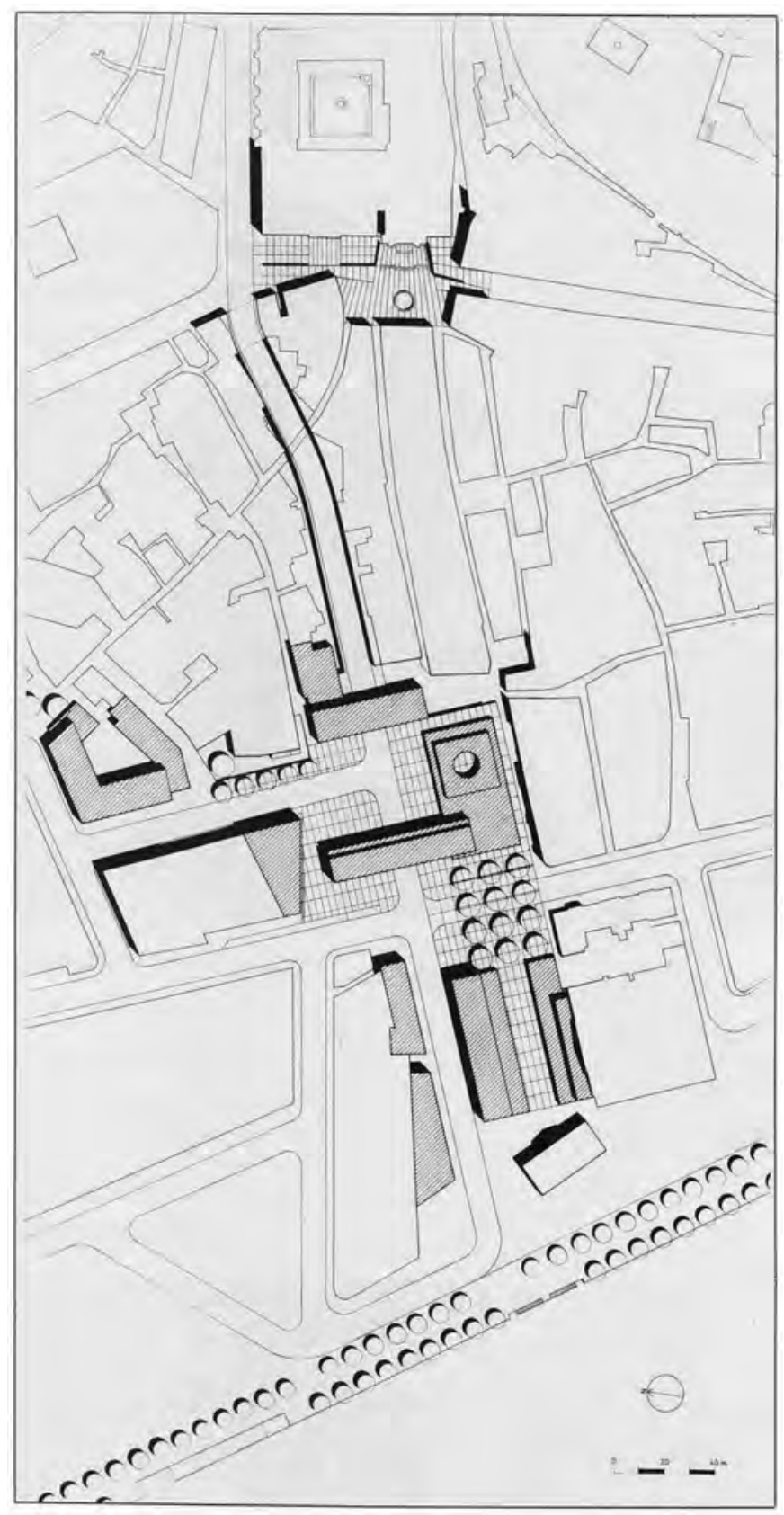

Figura 16

Eixo Bota Abaixo/Rio - Estudo Urbanistico, de Fernando Távora, 1992 


\section{Bibliografia}

Alarcấo, Jorge de (1999). A Evolução Urbanística de Coimbra: das origens a 1940, Coimbra: Cadernos de Geografia, n. ${ }^{\circ}$ especial Actas do I Colóquio de Geografia de Coimbra, pp. 1-10.

Almeida, Elisa (2005). Coimbra e o Rio Mondego. Coimbra: Câmara Municipal de Coimbra, texto para catálogo da exposição de cartografia Evolução do Espaço Físico de Coimbra, policopiado, $6 \mathrm{p}$.

Calmeiro, Margarida Isabel Barreto Relvão (2015). Urbanismo antes dos Planos: Coimbra 18341934. Doutoramento em Arquitetura, na Especialidade de Teoria e História de Arquitetura Departamento de Arquitetura da Faculdade de Ciências e Tecnologia da Universidade de Coimbra (policopiado).

Câmara Municipal de Coimbra (2004). Atitudes de Planeamento. Coimbra: Câmara Municipal de Coimbra, Divisão de Planeamento Urbanístico e Projetos Especiais.

Câmara Municipal de Coimbra (2004). Urbanismo Coimbra Anos 90. Coimbra: Câmara Municipal de Coimbra, Divisão de Planos.

Coimbra Viva SRU (2007). Documento Estratégico para a Primeira Unidade de Intervenção na Cidade de Coimbra. Coimbra Viva SRU - Sociedade de Reabilitação Urbana, S.A. (policopiado, cocoordenaçáo c/ Rui Passos Mealha).

Costa, José Cecílio da et al. (1893). Projeto de esgoto e saneamento da cidade de Coimbra. Lisboa: Revista de Obras Publicas e Minas, n. ${ }^{\circ} 24$, pp. 18-47.

Dionísio, Sant'Anna, Coord. (1993, 1. a ediçăo 1944). Guia de Portugal, Beira Litoral, $3^{\circ}$ vol., Coimbra: Fundaçāo Calouste Gulbenkian.

Faria, José Santiago (2005a). O Centro Histórico de Coimbra, aniquilaçấo, preservação e reabilitaçâo. Coimbra: 2.o Seminário - A intervenção no Património, Práticas de conservação e Reabilitação (policopiado).

Faria, José Santiago (2005b). Evolução do Espaço Físico de Coimbra. Coimbra: Câmara Municipal de Coimbra, texto para catálogo da exposição de cartografia Evolução do Espaço Físico de Coimbra, policopiado, $7 \mathrm{p}$.

Fernandes, Mário Gonçalves (2005). Urbanismo e morfologia urbana no Norte de Portugal, 1852-1926. Porto: FAUP publicaçóes.

Fernandes, Mário Gonçalves (2005). Plano de Pormenor da Zona Ribeirinha Nascente em Vila do Conde: contributos de um geógrafo. Revista da Faculdade de Letras, Geografia, I Série, Vol. XIX, pp. 429-439.

Macedo, Marta (2005). Coimbra na segunda metade do século xıx. Coimbra: Câmara Municipal de Coimbra, texto para catálogo da exposição de cartografia Evolução do Espaço Físico de Coimbra, policopiado, 8 p.

Margarido, Ana Paula (1987). A Morfologia urbana da "Alta" de Coimbra - Ensaio sobre o traçado da malha e sua evolução. Cadernos de Geografia, n. ${ }^{\circ}$ 6, Instituto de Estudos Geográficos, Faculdade de Letras da Universidade de Coimbra, pp. 43-69.

Martins, Alfredo Fernandes (1983, 1. a edição 1951). "Esta Coimbra ..., Alguns apontamentos para uma palestra”. Coimbra: Cadernos de Geografia, n.o 1, Instituto de Estudos Geográficos, Faculdade de Letras da Universidade de Coimbra, pp. 35-78.

Matos, Mário Antunes de (1986). Os transportes urbanos de tracçấo eléctrica em Coimbra. Coimbra: Cadernos de Geografia, n. ${ }^{\circ}$ 5, pp. 197-207. 
Rebelo, Fernando (1999). Condicionalismos físico-geográficos na origem e no desenvolvimento da cidade de Coimbra. Cadernos de Geografia, n. ${ }^{\circ}$ especial Actas do I Colóquio de Geografia de Coimbra, pp. 11-13.

Rosmaninho, Nuno (2005). Coimbra no Estado Novo. Coimbra: Câmara Municipal de Coimbra, texto para catálogo da exposição de cartografia Evolução do Espaço Físico de Coimbra, policopiado, $13 \mathrm{p}$.

Rossa, Walter (1997). A cidade portuguesa.In Pereira, Paulo, dir., História da Arte Portuguesa, Vol. 3. Lisboa: Temas e Debates, pp. 233-323.

Rossa, Walter (2005). O espaço de Coimbra: da instalação da urbanidade ao fim do antigo regime. Coimbra: Câmara Municipal de Coimbra, texto para catálogo da exposiçáo de cartografia Evolução do Espaço Físico de Coimbra, policopiado, 8 p.

Santos, Lusitano dos (1983). Planos de urbanização para a cidade de Coimbra. Coimbra: Museu Nacional Machado de Castro.

Torres, João Agria (2005). Geo-informação: base para o conhecimento do território. Coimbra: Câmara Municipal de Coimbra, texto para catálogo da exposiçấo de cartografia Evolução do Espaço Físico de Coimbra, policopiado, 8 p. 